\title{
Functional Implications of Changes in the Senescent Brain: A Review
}

\author{
CHARLES H. M. BECK
}

SUMMARY: The morphological, chemical. and physiological changes in the brain accompaniing old age are reviewed. The deterioration of the striatal and hypothalamic dopaminergic systems were implicated in the onset of age related Parkinsonian-like slowing of performance

RESUMÉ: L'auteur passe en revue les changements morphologiques, physiologiques, et chimiques qui accompagnent la vieilesse. La détérioration des spstèmes dopaminergiques stries et hypothalamiques est associée chez les vieillards aux phénomenes de ralentissement de performance du type Parkinsonien. et aux

Reprint recuests 10: Charles Beck, Department of Psychology. Biologieal Sciences Building, University of Alberta. I:dmonton, Alberta, T6G; 2E9, Canada.

Supported by a grant from the Medical Research Council.

From the Neuropsychology Unit. Department of Psychology. University of Atberta, Edmonton, Alberta. and altered affect. Cholinergic hippocampal and neocortical systems were chomically and physiologically abnormal in the aged. The implications for slowed cognitive processing and persistance of the memory irace are presented.

emorions modifiée. Les sụstèmes cholinergiques de l'hippocampe et du néocortex manifestent aussi chez les vieillards des anormalités phisiologiques et chimiques. L'auteur discute les implications de ces changements pour la domaine des processus cognitifs et pour la persistence des traces de mémoire.

Dementia refers to a progressive loss of the mental faculties. The most common cause of a progressive impairment of the mental faculties in the older adult population is the degenerative brain disease known as senile dementia. If the disease begins before the age of 65 years it is referred to as presenile dementia or Alzheimer's disease. Presenile and senile dementia are diseases of nervous tissue as opposed to atherosclerotic dementia which is a degenerative disease of the circulatory system. Together these two categories account for the majority of all cases of degenerative brain disease in the aged. The incidence of senile dementia is twice as high in women as in men. The proportions are reversed for atherosclerotic dementia (Roth, reported by Kent, 1977).

The mental symptoms of senile dementia, from the clinician's viewpoint, include flattening of affect, confusion in spatial and temporal orientation, impairment of memory especially for recent events, and a general slowing of movements and though processes. The onset is gradual, beginning with a dislike for change, a reduction in ambition and activity, an increased difficulty in comprehension and an increase in time and effort necessary for performance of familiar duties. Presenile dementia is viewed as an acceleration of this process of mental deterioration (Kolb. 1968).

The first section of this paper describes the physically visable, i.e., morphological changes, that can be seen in aging brain. Although the discussion will be restricted to the literature on normally aging individuals and people with presenile and senile dementia, it is noteworthy that a higher than normal incidence of the same physical signs have been observed in Down's syndrome retardates (Ohara, 1972) and Parkinson patients (Hirano, 1970). Down's syndrome retardates develop the symptoms by age 35 years. In addition to reviewing the physical signs of dementia, the first section of the paper will discuss the functional implications of these signs.

The second portion of the paper describes the chemical and physiological correlates of the aging process and outlines their functional implications. In the third and final section there is a detailed analysis of the behavioral scientist's perspective of aging.

\section{MORPHOLOGICAL SIGNS OF AGING} IN THE BRAIN

Physical evidence for a diagnosis of presenile dementia includes the presence in the brain of (1) senile plaques containing amyloid, an immunoglobulin byproduct; (2) tangles of neurofibrils, normally longitudinally arranged in the nerve fiber and thought to participate in the 
transport of vital substances along neurons; (3) areas of degeneration, consisting of silver staining granules surrounded by spaces or vacuoles; (4) collections of lipofuscin or age pigment inside neurons, representing an accumulation of oxidized nerve cell membranes; and (5) loss of nerve cells.

It is widely held that the pervasiveness of these signs is positively correlated with the degree of dementia both for patients stricken before age 65 and for those afflicted later in life (Blessed et al., 1968). However, it is not generally recognized that virtually all people by 80 years of age present similar, though less invidious, examples of the same physical pathology (Dayan, 1970; Gellerstedt, 1931; Matsuyama et al., 1966). There is a positive correlation between age related cell loss, severity of tangle formation, and degree of granulovacuolar degeneration in both normals and dements. However, the yearly rate of cell loss is five times as great in the Alzheimer patients as in normal persons (Ball, 1977; Ball and Lo, 1977).

Brody (1955) hypothesized that the degree of dementia is directly related to the incidence of cell loss. MeierRuge (1975) suggested that this hypothesis is untenable because subsequent studies of senescent rodent brains have revealed less than $1 \%$ cell losses (Brizzee et al., 1968; Klein and Michel, 1977). However, these studies examined only the rodent neocortex. Studies of the old rodent's medial dorsal nucleus of the thalamus (Stein and Firl, 1976) and hippocampus (Vijayan, 1977) showed serious degeneration. In humans the physical signs enumerated above appear in many parts of the brain including the neocortex. However, the pathology has a predilection for the hippocampus and in Alzheimer's disease for the posterior hippocampus in particular (Ball, 1977; Brizee et al., 1974; Gellerstedt, 1931). The magnitude of the hippocampal cell loss by 70 years of age is fairly substantial. There is approximately $12 \%$ cell loss in normals and $60 \%$ in presenile dements (Ball, 1977). Damage to the medial dorsal thalamus and hippocampus has been related to memory impairments in humans (Milner, 1970; Victor et al, 1971). The memory deficits of the demented and aged have been attributed to hippocampal damage (Ball, 1977; Malamud, 1972). Other authors (Brizzee et al., 1974; Scheibel et al., 1975, 1976) prefer to emphasize the importance of the diffuseness of the signs of physical damage throughout the brain, in accounting for general slowing of information processing accompanying aging.

Prior to the disintegration of the nerve cell body there is an age related deterioration of axonal (output) and dendritic (input) terminal processes (Bondareff and Geinisman, 1976; Machado-Salas et al., 1977; Scheibel et al., 1975, 1976).

In summary, morphological changes in the brain with age provide a picture of gradual degeneration and cell loss, especially in structures involved in memory. The normal aging process is accelerated in Alzheimer's disease and Down's syndrome. Theories of aging emphasize either the relation between hippocampal degeneration and memory deficits or that between diffuse degeneration and slowed processing. The functional implications of neurofilbrillary tangles and cell membrane instability will be detailed in the next section of the paper.

\section{CHEMICAL AND PHYSIOLOGICAL SIGNS OF AGING IN THE BRAIN}

The most prominent theory of aging is the error catastrophe theory of Orgel (1963; Comfort, 1974). In all tissue, the RNA transcription of the genetic code for protein has an increased error rate with age, resulting in the age related decline in levels of critical enzymes. Thus there is an age associated decline in uptake, turnover, and utilization of amino acids and a decline in RNA biosynthesis of enzymes (Tonna and Singh, 1976). In general, biochemical anabolic functions deteriorate through the loss of enzymes controlling carbohydrate, intermediate protein, and lipid metabolism (Roberts et al., 1976). With age, a decrease occurs in glucose oxidation (Patch, 1977) and in formation and utilization of ATP, an energy source (Ermini et al., 1971; Sun and
Samorajski, 1975). This results in a reduction in oxygen turnover (Chen et al., 1972). One would predict from this a reduced cerebral blood flow with age and with increasing dementia and this is indeed the case (Lassen et al., 1960; Ingvar and Lassen, 1970; Simard, 1971). Slowing of cerebral blood flow occurs over the temporal region in the brains of memory impaired senile patients, and in the parieto-occipitotemporal region in patients with aphasia symptoms (Hagberg and Ingvar, 1976; Obrist et al., 1970). Since old people have a greater arteriovenous $\mathrm{O}_{2}$ content difference, indicating the brain is extracting more $\mathrm{O}_{2}$ per unit of blood (Dastur et al., 1963), and since the cerebral capillary network of the senescent brain is more extensive than that of the younger person (Huziker et al., 1978), the diminished cerebral blood flow is more likely a product of metabolic than morphological variables.

In presenile and senile dementia, but not in atherosclerotic dementia, the occurrence of neurofibrillary tangles is proportional to the accumulation of aluminum in the brain cells (Crapper et al., 1976). The concentration of aluminum in Alzheimer patients is four times that in normal patients (Crapper, 1974; Crapper et al., 1973). Implantation of aluminum into the brains of animals results in neurofibrillary tangles indentical to those in senile humans' brains (Terry and Pena, 1965). Aluminum disrupts protein synthesis in nerve cells (Miller and Levine, 1974). The origin of the metabolic error causing the aluminum accumulation is unknown.

Another anabolic process which deteriorates with aging is that of the synthesis, release, and uptake of neurotransmitters. Old brains experience $25 \%$ slower rate and $50 \%$ reduced volume of axonal transport of substances essential for transmitter production (Geinisman et al., 1977a, 1977b), a shortage of the enzymes necessary for transmitter synthesis (McGreer et al., 1977; Spillane et al., 1977: Vijayan, 1977), an impairment of waste reducing uptake of unused neurotransmitter (Jonec and Finch, 1975; Sun, 1976), fewer transmitter receptor binding sites (White et al., 
1977), reduced number of neurotransmitter storage vesicles (Sun, 1976), and lowered sensitivity of the chemical response of the receiving neuron to delivered neurotransmitter (Govoni et al., 1977, Spano et al., 1975).

Conversely, products which degrade or catabolize neurotransmitters increase with aging. Acid phosphatases, perioxidases, monamine oxidase, and catechol-o-methyl transferase all increase in the old brain (Broch, 1973; Brunk and Ericcson, 1972; Robinson et al., 1977). The latter two molecules degrade the catecholamine transmitters, dopamine and norepinephrine.

If the neurotransmitter changes referred to above affected systems controlling behaviors which deteriorated with age, then it is apparent that the hehavioral deficits of the aged would be ascribable to metabolic dysfunction rather than frank cell loss as the primal causal agent. The evidence for this view is growing. The aging brain undergoes a significant decline in the functional effectiveness of the dopamine system in the striatum (Finch, 1973; Govoni et al., 1977; McGeer et al., 1977; Robinson et al., 1977). There is also a decrease in the number of cells in the substantia nigra with age (McGeer et al., 1977). Behaviorally, this would mean that the normal aging process would move people toward the Parkinsonian ratio of excess acetycholine to dopamine in the critical system linking the substantia nigra and the striatum (McGreer et al., 1977). Thus one would expect slowness of movement, rapid fatiguing, tardy movement initiation, loss of associated movements, and diminished kinetic grace, characteristic of Parkinson patients, to become more obvious with advancing age. Evidence that the same dopaminergic deficit may be responsible for a flattening of affect and a loss of incentive motivation is available (Phillips and Fibiger, 1973).

The ergot alkaloids, e.g., dihydroergotoxine. which stabilize the terminal membranes of dopaminergic neurons (Goldstein et al., 1978; Spano and Trabucchi, 1978) protect the organism against the metabolic effects of reduced blood flow (Boismare et al.,
1978; Gygax et al., 1978) and alleviate the complaints of the aged (Bazo, 1973; Hoffbrand et al., 1976). No one has described the effects of the ergot alkaloids on the physical signs of cerebral senescence.

Dopamine is released by certain nerve terminals in the retina in response to light (Kramer, 1971). In aged mammals the cells receiving the dopamine become hypersensitive to released dopamine (Spano et al., 1975) in an attempt to compensate for functional dopaminergic dennervation (Govoni et al., 1977). It is possible that such paradoxical hypersensitivity may contribute to the longer dark adaptation time (Reading, 1968) and the increased aggravation from light glare (Wolf, 1960) experienced by old people. Usually the effects are attributed to increased opacity of the lens and cornea.

Calcium ion concentrations increase in muscle (Gutmann and Hanzlikova, 1972) and nervous tissue with aging (Sun and Seaman, 1977). This may be related to abnormally low levels of parathyroid hormone in the senescent (Fujita et al., 1976). Calcium plays an important role in neurotransmitter release. The redressing of the $\mathrm{Ca}^{+}$imbalance has been suggested as the mechanism underlying the efficacy of chronic chlorpromazine therapy in reducing neuronal lipofuscin accumulation (Samorajski and Rolsten, 1976). Chlorpromazine has multiple effects on release and uptake of dopamine and norepinephrine.

Chemical blocking of pathways requiring the neurotransmitter acetylcholine impairs performance on memory tests. The deficits were similar to those observed in normal old persons (Drachman and Leavitt, 1974). Many neurons terminating in the hippocampus release acetylcholine. There is a significant age related decline in the hippocampal concentration of the enzyme necessary for acetylcholine synthesis (Perry et al., 1977; Vijayan, 1977). This decline is even more marked in Alzheimer patients, but not in chronic schizophrenics, chronic unipolar depressives, or multi-infarct dements. It is significant in degree not only in the hippocampus but also in the frontal, parietal, temporal, and occipital cortices of Alzheimer patients (Perry et al., 1977). Normal old people do not experience significant declines in acetylcholine enzyme levels outside the hippocampus (Perry et al., 1977). The dysfunction in Alzheimer patients is presynaptic, i.e., in acetylcholine synthesis, rather than an impairment in postsynaptic receptor site sensitivity (Perry et al., 1977; Spillane et al., 1977; White et al., 1977). Such abnormality is consistent with electron microscopic evidence of gross degenerative changes in presynaptic structures and the normal appearance of receptor membranes (Wisniewski and Terry, 1976). The greater the depletion of the cholinergic enzyme, the greater the degree of neurofibrillary tangles evident (White et al., 1977). Geinisman et al. (1977a, 1977b) suspect that the tangles may be partly responsible for the reduced availability of the enzyme at presynaptic membranes.

In response to stress, the medulla of the adrenal gland liberates a number of neurotransmitter substances into the blood stream. The urinary and blood plasma levels of epinephrine, norephinephrine, and dopamine betahydroxylase increase with age (Freedman et al., 1972; Giorgino et al., 1969; Kvetnansky et al., 1978) as does the size of adrenal medulla (Kvetnansky et al., 1978; Sotgiu et al., 1960). Hyperfunction of the adrenal medulla in the aged coupled with their exaggerated sensitivity to its hormones (Frolkis et al., 1972) may be related to increased incidence of hypertension, atherosclerosis, and cardiac infarction in old people (Kvetnansky et al., 1978).

The hippocampus is capable of inhibiting the secretion of adrenocorticotrophic hormone from the anterior pituitary. This hormone controls secretions of other hormones, e.g., corticosterioids, from the cortex of the adrenal gland. Neurons of the hippocampus have receptor sites for one of the corticosteriods, namely corticosterone. Corticosterone modulates the genetic processes governing anzyme synthesis in the hippocampus (Lee et al., 1977). These enzymes are necessary for neurotransmitter production and, as noted above, are 
depleted in old age (Perry et al., 1977). There is a positive correlation between the degree of hippocampal neuron degeneration in the individual and the resting levels of corticosterone in the blood plasma (Landfield and Lynch, 1977). Resting plasma corticosterone level decreases in old age. Continued degeneration of the hippocampus with senescence may result from increased sensitivity to the circulating hormones (Frolkis et al., 1972). It would be interesting to measure corticosterone levels and sensitivity in Alzheimer patients.

In summary, the senescent brain experiences dysfunctional biases toward the Parkinsonian state of striatal dopamine depletion and consequent slowing of movement as well as toward mnemonic impairment precipitated by hypofunction of the hippocampal and cortical cholingergic systems. A common age related deterioration of the genetically controlled transcription of protein may underly both trends.

\section{RELATED BEHAVIORAL SIGNS OF AGING}

Whether intelligence as defined by the traditional intelligence test does decline with age (Birren and Morrison, 1961; Williams, 1970) or does not (Barton et al., 1975; Ford and Roth, 1977; Schaie et al., 1973) appears to depend on methodological issues which are not central to theme of this review. Two main categories of subtests in these and more recent batteries (Branconnier and Cole, 1978; Shader et al., 1974) appear to be age sensitive. These are speeded subtests and the memory subtests.

The memory deficit of the aged is not specific for any particular mnemonic subfunction such as memory storage capacity (Eber, 1976; cf. Salthouse, 1978); level of memory processing (Eysenck, 1974; Zelinski et al., 1978; cf. Mergler et al., 1977); ignoring irrelevant stimuli (Rabbitt, 1965; cf. Klauser and Kleim, 1978); registration as opposed to retrieval (Adamowicz, 1976), or on long versus short delays of recall (Schreider et al., 1975). Rather, the deficit seems to be a general slowing of information processing (Adamowicz, 1976). This suggests that the speeded and memory categories of subtests are measuring the same thing. For example, memory tests would produce "speed" deficits if the pace of stimulus presentation and response production is too rapid for the old person. When taken to identical original learning criteria, young and old are no different on subsequent recall (Hulicka, 1965). When allowed to pace themselves, the elderly took longer to learn the task than did young persons but did just as well as the young on recall tests (Adamowicz, 1976). Total learning time available rather than rate of presentation is the critical variable (Winn and Elias, 1977).

If the slowed processing were a general characteristic, one would expect an increased deficit with the amount of information processed on verbal tasks (Anders and Fozard, 1973; Klauser and Klein, 1978) and on nonverbal tasks (Benton, 1977; Fozard et al., 1976); slowed retrieval search of both primary and secondary memory (Anders and Fozard, 1973), and slowed rotation and comparison of spatial depth figures (Gaylord and Marsh, 1975). The studies cited have demonstrated these effects with the normal aged.

Partitioning of the total response time into reaction time and movement time revealed that both were slow in the aged and that the reaction time was responsible for the greatest part of the deficit (Spirduso, 1975). Retarded movement time was attributable to slower peripheral nerve conduction velocity (Retzlaff and Fontaine, 1965), loss of muscle fiber mass (Gutmann and Hanzlikova, 1976), decreased frequency of miniature end-plate potentials and slowed contraction coupling time (Gutmann and Hanzlikova, 1972).

Several mechanisms may contribute to the slowed reaction time. Raised sensory thresholds (Clark and Mehl, 1971; Dyck et al., 1972, 1974; Harkins and Chapman, 1976; Kokmen et al., 1978; Whanger and Wang, 1974) and slowed conduction time of brain neurons would at best contribute $10 \%$ to the total retardation of the reaction time (Retzlaff and Fontaine, 1965). A more significant factor would be the hypofunction of the dopaminergic system discussed above. McGeer's (1977) hypothesis was that the dopaminergic bias in the aged is toward that of the Parkinsonian neuropathology. Parkinson patients exhibit not only slowed movement times but also slowed pre-electromyographic reaction times (Brumlick and Boshes, 1966). Parkinson patients persist in an error response for a longer duration on tracking tasks than do normal individuals (Angel et al., 1970; Bowen et al., 1972). The degree to which simple stimuli persist in memory, as measured by the critical flicker fusion test, increases with increasing severity of Parkinson movement dysfunction (Riklan et al., 1970). Personality inflexibility as measured by the F-Scale increases in the same manner (Ploski et al., 1966). Comparable examples of stimulus trace persistance and response mode persistance for the aged will be described below.

Another mechanism that may contribute to slowed processing is dysfunction of the hippocampal cholinergic system. Damage to the hippocampus causes the organism to fail to adjust to changing reinforcement contingencies and to fail to habituate to novel stimuli (Kimble, 1968). The organism tends to persist in performing current or habitual modes of responding. It is possible that the slowness of the aged is partly the result of a tendency to prolong the response to internally or externally generated stimuli (Axelrod, 1963; Botwinick, 1973). If the subsidence of the neural response to the initial stimulus is slow, the perception of the second stimulus would be retarded and slowed processing of information would result. If this were the case one would look for evidence in the aged of the persistance of brief images at the registration level and for the perseveration of sets at the cognitive level.

Exaggerated persistance of the iconic trace has recently been demonstrated to result in superior performance in the recognition of fragmented words in the aged compared to the young (Kline and Orme-Rogers, 1978). Complementary halves of a single word were flashed on 
a screen one after the other. If the persistance of the trace of the initial word half in the mind of the viewer was superimposed on the flash of the second half of the word, recognition of the word would result. Old people were especially superior for the longer intervals between word fragments. In addition, old persons show enhanced persistance of complementary afterimages (Kline and Nestor, 1977), and, as one might expect, poor temporal resolution of shocks to the skin (Axelrod et al., 1968), slowed temporal processing of auditory stimuli (Corso, 1975), lowered visual critical flicker fusion thresholds (Misiak, 1951; McFarland et al., 1958), lowered auditory click fusion thresholds (Weiss, 1959), protracted susceptibility to backward masking (Kline and Szafran, 1975), and longer lasting visual evoked responses to photic stimulation (Mundy-Castle, 1953). It is easy to see how such persistance, if also applicable to items retrieved from primary of secondary memory, would slow down retrieval search time (Anders and Fozard, 1973).

When one speaks of secondary and permanent memory one usually speaks of perseveration of sets rather than persistance of traces. Old people perseverate in viewing ambiguous figures in only one mode (Botwinick et al., 1959), persist in viewing the Necker cube in only one view (Heath and Orbach, 1963), and fail to reverse the figure ground relationship in order to read ambiguous words (Kline et al., 1977). Tasks requiring a shifting of problem solving set are expecially taxing for the aged (Botwinick et al., 1957, 1958, 1959; Goodrick, 1972; Heglin, 1956). Old people have anecdotally described the persistance with which unwanted tunes and thoughts run through their minds.

What can be done to postpone the development of senility? As previously noted the ergot alkaloids and phenothiazines may offer some hope. At the present time the largest contribution to longevity variance in the healthy rat is the factor controlled by diet (Ooka et al., 1978; Ross and Lustbader, 1976; Segall et al., 1978). There is some evidence that training may modulate cognitive deficits in the elderly (Birkhill and Schaie, 1975; Hoyer et al., 1973; Plemons et al., 1978). Physical exercise seems definitely to influence physiological performance (Retzlaff and Fontaine, 1965; de Vries, 1971) and reaction time (Spirduso, 1975; Spirduso and Clifford, 1978). The last study is especially provocative since exercising men in their sixties performed with reaction times comparable to men in their twenties. One would like to know what would be the iconic trace persistance times and retrieval search times of those active oldsters.

In conclusion, evidence has been presented for an age dependent slowing of information processing. Such an impairment may relate to persistance of sensory traces and perseveration of cognitive sets. Persistance would be an advantage only in tasks in which retention of a single item or mode of response was required. Serial search or serial learning tasks would produce deficits in performance, unless there was adequate time for shifts between items.

Evidence has been presented that dysfunction in dopaminergic and cholinergic brain systems may underly these persistance effects. Avenues for future research suggest themselves. Persistance measures have not been applied to the other types of human abiotrophies (Bowen et al., 1976) or their animal models (Crapper, 1974; Ungerstedt, 1971). One disturbing possibility is that schizophrenia which supposedly has a dopaminergic bias opposite in direction to that of Parkinsonism is also said to be characterized by slow information processing (Davidson and Neale, 1974; Saccuzzo et al., 1974; Yates, 1966; Yates and Korboot, 1970) and trace persistance (Gruzelier et al., 1972). It would be helpful to know whether the persistence measures in the aged are changed by exercise or drug therapy. The hypothesis that persistance and perseveration beget cognitive slowing needs to be examined. Are the three tightly correlated or can they be dissociated? Possibly it will be found that persistance and perseveration always result in slowing of information pro- cessing, but that slowing may occur as a result of other causes, for example excessive caution (Birkhill and Schaie, 1975).

\section{REFERENCES}

ADAMOWICZ, J. K. (1976). Visual short-term memory and aging. Journal of Gerontology $31,39-46$.

ANDERS, T. A. and FOZARD, J. I. (1973). Effects of age upon retricval from primary and secondary memory. Developmental Psychology 9,411-415.

ANGEL, R. A., ALSTEN, W. and HIGGiNS, J. R. (1970). Control of movement in Parkinson's disease. Brain 93.1-15.

AXELROD, S. (1963). Cognitive tasks in several modalities. In Processes of Aging, edited by R. H. Williams, C. Tibbitts and W. Donahue, Atherton Press, New York, Vol. 1. pp. 132145.

AXELROD, S., THOMPSON, L. W. and COHEN, L. D. (1968). Effects of senescence on the temporal resolution of somesthetic stimuli presented to one hand or both. Journal of Gerontology 2. 191-195.

BALL. M. J. ( 1977). Neuronal loss, neurofibrillary tangles and granulovascular degeneration in the hippocampus with aging and dementia. A quantitative study. Acta Neuropathologica 37. $11-118$.

BALL. M. J. and L.O. P. (1977). Granulovacuolar degeneration in the aging brain and in dementia. Journal of Neuropathology and Experimental Neurology. 36. 474-487.

BARTON, E. M., PI.EMONS, J. K., WII.I.IS, S. L. and BAL.TES. P. B. (1975). Recent findings on adult and gerontological intelligence: changing a stereotype of decline. American Behavioral Scientist 19. 224-236.

BAZO, A. G. (1973). An ergot aklaloid preparation (hydergine) versus papaverine in treating common complaints of the aged: a double blind study. Journal of American Geriatric Society' 21, 63-71.

BENTON, A. L. (1977). Interactive effects of age and brain disease on reaction time. Archives of Neurology 34, 369-370.

BIRKHIL.L. W. R. and SCHAIE, K. W. (1975). The effect of differential reinforcement of cautiousness in intellectual performance among the elderly. Journal of Gierotology 30, $578-583$.

BIRREN, J, E. and MORRISON, D. F. (I96I). Analysis of the WAIS subtests in relation to age and education. Journal of Gerontology 16, 363-369.

BLESSED. G.. TOMLINSON, B. E. and ROTH. M. (1968). The association between quantitative measures and senile changes in the cerebral gray matter of elderly subjects. British Journal of Psychiatry 114. 797-802.

BOISMARE. F.. I.E PONCIN, $M$, and LEFRANCOIS. I. (1978). Biochemical and behavioral effects of hypox hypoxia in rats: Study of the protection afforded by ergot alkaloids. Gerontology 24, Suppl. 1, 6-13. 
BONDAREFF, W. and GEINISMAN, $Y$ (1976). Loss of synapses in the dentate gyrus of the senescent rat. American Journal of Anatomy 145. 129-136.

BOTWINICK. J. (1973). Aging and Behavior, Springer. New York, p. 132.

BOTWINICK. J., BRINLEY, J. F. and BIRREN. J. E. (1975). Set in relation to age. Journal of Gerontology 12,300-305.

BOTWINICK, J., BRINLEY, J. F. and ROBBIN, J. S. (1958). Task alternation time in relation to problem difficulty and age. Journal of Gerontology 13, 414-417.

BOTWINICK. J., BRINLEY, J. F. and ROBBIN. J. S. (1959). Modulation of speed of response with age. Journal of Genetic Psychology 95, 137-144.

BOTWINICK, J., ROBBIN. J. S. and BRINLEY, J. F. (1959). Reorganization of perceptions with age. Journal of Gerontology 14, 85-88.

BOWEN, D. M.. SMITH, C. B., WHITE, P. and DAVISON, A. N. (1976). Neurotransmitter-related enzymes and indices of hypoxia in senile dementia and other abiotrophics. Brain 99, 459-496.

BOWEN, F. P., HOEHN, M. M. and YAHR, $M$. D. (1972). Cerebral dominance in relation to tracking and tapping performance in patients with parkinsonism. Neurology 22. 32-39.

BRANCONNIER, R. J. and COLE, J. O (1978). The impairment index as a symptomindependent parameter of drug efficacy in geriatic psycho-pharmacology. Journal of Gerontology 33, 217-223.

BRIZZEE, K. R., ORDY, J. M. and KAACK B. (1974). Early appearance and regional differences in intraneuronal and extraneuronal lipofuscin accumulation with age in the brain of a nonhuman primate. Journal of Gerontology 29. 366-381.

BRIZZEE, K. R., SHERWOOD, N. and TIMIRAS, P. S. (1968). Comparison of cell populations at various levels in the cerebral of young adult and aged Long-Evans rats. Journal of Gerontology 23, 289-297.

BROCH, O. J., JR. (1973). The post natal development of catechol-o-methyl transferase in the rat brain. Journal of Neurochemistry 20. 847-852.

BRODY, H. (1955). Organization of the cerebral cortex. III. A study of aging in the human cerebral cortex. Journal of Comparative Neurology 102, $511-556$.

BRUMLICK. J. and BOSHES, B. (1966). The mechanism of bradykinesia in parkinsonism. Neurology 16, 337-344.

BRUNK, U. and ERICCSON, J. L. E. (1972) Electron microscopic studies on rat brain neurons. Localization of acid phosphatase and mode of formation of lipofuscin bodies Journal of Ultrastructure Research 38, I-38.

CHEN, J. C., WARSHAW, J. B. and SANADI, D. R. (1972). Regulation of mitochondrial respiration in senescence. Journal of Cellular \& Comparative Physiology 80, 141 148.
CLARK, W. C. and MEHL, L. (1971). Thermal pain: A sensory decision theory analysis of the effect of age and sex on $d^{t}$, various response criteria and $50 \%$ pain threshold. Journal of Abnormal Psychology 78, 202212

COMFORT, A. (1974). The position of aging studies. Mechanisms of Aging \& Development 3, 1-31.

CORSO, J. F. (1975). Sensory processes in man during motility and senescence. In Neurobiology of Aging, edited by J. M. Ordy and K. R. Brizzee, Plenum, New York. pp. 119-143.

CRAPPER, D. R. (1974). Dementia: Recent observations in Alzheimer's disease and experimental aluminum encephalopathy. In Frontiers in Neurology and Neuroscience Research, edited by P. Seeman and G. M. Brown, Toronto, University of Toronto Press, pp. 97-111.

CRAPPER, D. R., KRISHNAN, S. S, and DALTON, A. J. (1973). Brain aluminum distribution in Alzheimer's disease and experimental neurofibrillary degeneration. Science 180,511-513.

CRAPPER, D. R., KRISHNAN, S. S. and QUITTKAT, S. (1976). Aluminum, neurofibrillary degeneration and Alzheimer's disease. Brain 99. 67-80.

DASTUR, D. K., LANE, M. H., HANSEN, D. B., KETY, S. S., BUTLER, R. N., PERLIN, S. and SOKOLOFF, L. (1963). Effects of aging on cerebral circulation and metabolism in human aging: A biological and behavioral study. Washington, D.C. Public Health Service Publication, United States Government Printing Office, No. 986.

DAVIDSON. G. S. and NEALE, J. M. (1974). The effects of signal-noise similarity on visual information processing in schizophrenics. Journal of Abnormal Psychology 83, 683-686.

DAYAN, A. D. (1970). Quantitative histological studies on the aged brain. 11. Senile plaques and neurofibrillary tangles in senile dementia. Acta Neuropathological 16,95102.

DRACHMAN, D. A. and LEAVITT, J. (1974). Human memory and the cholinergic system. Archives of Neurology 30, 113-121.

DYCK, P. J., CURTIS, D. J., BUSHEK, W. and OFFORD, K. (1974). Description of "Minnesota Thermal Disks" and normal values of cutaneous thermal discrimination in man. Neurology 24, 325-330.

DYCK, P. J.. SCHULTZ. P. W. and O'BRIEN, P. C. (1972). Quantitation of touch pressure sensation. Archives of Neurology 26, 465473

EBER, J. T. (1976). Age differences in learning and memory on a digit symbol substitution task. Experimental Aging Research 2, 45-53.

ERMINI, M. SZELENYI, J., MOSER, P. and VERZAR, F. (1971). The aging of skeletal (striated) muscle by changes of recovery metabolism. Gerontologia 17, 300-311.
EYSENCK, M. W. (1974). Age differences in incidental learning. Developmental Psychology 10, 936-941.

FINCH, C. E. (1973). Catecholamine metabolism in the brains of aging male mice. Brain research $52,261-276$.

FORD, J. M. and ROTH, W. T. (1977). Do cognitive abilities decline with age? Geriatrics 32, 59-62.

FOZARD, J. L., THOMAS, J. C., JR. and WAUGH, N. C. (1976). Effects of age and frequency of stimulus repetitions on twochoice reaction time. Journal of Gerontology 31, 556-563.

FREEDMAN, L. S., OHUCHI, T., GOLDSTEIN, M., AXELROD, F., FISH, I. and DANCIS, J. (1972) Changes in human serum dopamine- $\beta$-hydroxylase activity with age. Nature 236, 310-311.

FROLKIS, W., BEZRUKOV, V. V. and SINITSKY, V. N. (1972). Sensitivity of central nervous structures to humoral factors in aging. Experimental Gerontology 7, 185-194.

FUJITA, T., OHATA, M., OTA, K., TSUDA, T., UEZI, A., OKANO, K. and YOSHIKAWA, M. (1976). Aging and parathyroid hormone secretion. Journal of Gerontology 31, 523-526.

GAYLORD, S. A. and MARSH, G. R. (1975). Age differences in the speed of a spatial cognitive process. Journal of Gerontology 30, 674-678.

GEINISMAN, Y., BONDAREFF, W. and TELSER, A. (1977a). Transport of $\left({ }^{3} \mathrm{H}\right)$ frucose labeled glycoproteins in the septohippocampal pathway of young adult and senescent rats. Brain Research 25, 182-186.

GEINISMAN, Y., BONDAREFF, $W$. and TELSER, A. (1977b). Diminished axonal transport of glycoprotein in the senescent rat brain. Mechanisms of Aging and Development 6, 363-378.

GELLERSTEDT, E. (1931). Klinisch-generalogischer Nachweis von Erblichkeit bei Pickscher Krankheit. Zeitschrift fur Neurologische Psychiatrie 136, 464-471.

GIORGINO, R., SCARDAPANE. R.. NARDELLI, G. M. and TAFARO, E. (1969). Adrenal glands and aging: Aspects of medullary activity. Folia Endocrinology 22 215-224

GOLDSTEIN, M.. LEW, J. Y.. HATA, F. and LIEBERMAN, A. (1978). Binding interactions of ergot alkaloids with monoaminergic receptors in the brain. Gerontology 24, Suppl. 1, 76-85.

GOODRICK. C. L. (1972). Learning by mature young and aged Wistar albino rats as a function of test complexity. Journal of Gerontology 27. 353-357.

GOVONI, S., LODDO, P., SPANO, R. F. and TRABUCCHI, M. (1977). Dopamine recept or sensitivity in brain and retina of rats during aging. Brain Research 138, 565-570.

GRUZELIER. J. H., LYKKEN, D. T. and VENABLES, P. H. (1972). Schizophrenia and arousal revisited. Archives of General Psychiatry 26, 427-432. 
GUTMANN, E. and HANZLIKOVA, V. (1972) Basic mechanisms of aging in the neuromuscular system. Mechanisms of Aging and Development. 1, 327-349.

GUTMANN, E. and HANZLIKOVA, V. (1976) Fast and slow motor units in ageing. Gertontology 22, 280-300.

GYGAX, P., WIERNSPERGER, N., MEIERRUGE, W. and BAUMANN, T. (1978). Effect of Papaverine and dihydroergotoxine mesylate on cerebral microflow, EEG and $\mathrm{pO}_{2}$ in oligemic hypotension. Gerontology 24 Suppl. 1, 14-22.

HAGBERG, B. and INGVAR, D. H. (1976). Cognitive reduction in presenile dementia related to regional abnormalities of the cerebral blood flow. British Journal of Psychiatry 128, 209-222.

HARKINS, S. W. and CHAPMAN, R. (1976). Detection and decision factors in pain perception in young and elderly men. Pain 2 , 253-264.

HEATH, A. and ORBACH, J. (1963). Reversibility of the necker cube: IV Responses of elderly people. Perceptual and Motor Skills 17, 625-626.

HEGLIN, H. J. (1956). Problem solving set in different age groups. Journal of Gerontology II, 310-317.

HIRANO, A. (1970). Neurofibrillary changes in conditions related to Alzheimer's disease. In Alzheimer's Disease and Related Conditions, edited by G. E. W. Wolstenholme and $M$. O'Connor, London, Churchill, pp. 185-200.

HOFFBRAND, B. I., MACLAY, W. P. and TURNER, P. (1976). Ergot compounds the changing scence. Post-graduate Medical Journal 52, Suppl. 1, 1-62.

HOYER, W. J., LABOUVIE, G, V. and BALTES, P. B. (1973). Modification of response speed deficits and intellectual performance in the elderly. Human Development 16, 233-242.

HULICKA, I. M. (1965). Age differences for intentional and incidental learning and recall scores. Journal of the American Geriatrics Society 13, 639-684.

HUZIKER, O., ABDEL'AL, S., FREY, H., VETEAU, $M-J$ and MEIER-RUGE, W. (1978). Quantitative studies in the cerebral cortex of aging humans. Gerontology 24, 27-31.

INGVAR, D. H. and LASSEN, N. A. (1970). Cerebral blood flow and cerebral metabolism. Triangle 9, 234-243.

JONEC, V. and FINCH, C. E. (1975). Aging and dopamine uptake by subcellular fractions of the C5713L/6J male mouse brain. Brain Research 91, 197-215.

KENT. S. (1977). Classifying and treating organic brain syndromes. Geriatrics 32, 8789, 93-96.

KIMBLE, D. P. (1968). Hippocampus and internal inhibition. Psychological Bulletin $70,285-295$.
KLAUSER, D. H. and KLEIM, D. M. (1978). Age differences in processing relevant stimuli in multiple-item recognition learning. Journal of Gerontology 33, 87-93.

KLEIN, A. W. and MICHEL, M. E. (1977). A morphometric study of the neocortex of young adult and old maze - differentiated rats. Mechanisms of Ageing and Development $6,44 \mid-452$.

KLINE, D. W., CULLER, M. P. and SUCEC, J. (1977). Differences in inconspicuous word identification as a function of age and reversible - figure training. Experimental Aging Research 3, 203-213.

KLINE, D. W. and NESTOR, S. (1977). The persistence of complementary after images as a function of adult age and exposure deviation. Experimental Aging Research 3, 191-201.

KLINE, D. W. and ORME-ROGERS, C. (1978). Examination of stimulus persistence as the basis for superior visual identification performance among older adults. Journal of Gerontology 33, 76-81.

KLINE, D. W. and SZAFRAN, J. (1975). Age differences in backward monoptic visual noise masking. Journal of Gerontology 30 , 307-311.

KOKMEN, E., BOSSEMEYER, R. W., JR. and WILLIAMS, W. J. (1978). Quantitative evaluation of joint motion sensation in an aging population. Journal of Gerontology 33, 62-67.

KOLB, L. C. (1968). Noyes' Modern Clinical Psychiatry, Philadelphia, W. B. Saunders, pp. 250-258.

KRAMER, S. G. (1971). Dopamine: a retinal neurotransmitter. I. Retinal uptake, storage and light-stimulated release of $\left[{ }^{3} \mathrm{H}\right]$ dopamine in vivo. Investigative Ophthalmology 10, 438-445.

KVETNANSKY, R., JAHNOVA, E., TORDA, T., STRBAK, V., BALAZ, V. and MACHO, L. (1978). Changes of adrenal catecholamines and their synthesizing enzymes during ontogenesis and aging in rats. Mechanisms of Ageing and Development 7, 209-216.

LANDFIELD, P. W. and LYNCH, G. S. (1977) Brain aging and plasma steroid levels: quantitative correlations. Neuroscience Abstracts 3, 111 .

LASSEN, N. A., FEINBERG, I. and LANE, $M$. H. (1960). Bilateral studies of cerebral oxygen uptake in young and aged normal subjects and in patients with organic dementia. Journal of Clinical Investigation 39. 491-500.

LEE, K. S., ETGEN, A. M. and LYNCH, G. S. (1977). Corticosterone modification of the synthesis of specific proteins in the central nervous system. Neuroscience Abstracts 3 , 350.

MACHADO-SALAS, J., SCHEIBEL, M. E. and SCHEIBEL, A. G. (1977). Neuronal changes in the aging mouse; spinal cord and lower brain stem. Experimental Neurology $54,504-512$.
MALAMUD, N. (1972). Neuropathology of organic bain syndromes associated with aging. In C. M. Gaitz (Ed.), Aging and the Brain. New York: Plenum Press, pp. 63-88.

MATSUYAMA. H., NAMIKI, H. and WATANABE. I. (1966). Senile changes in the brain in the Japanese. Incidence of Alzheimer's neurofibrillary change and senile plaques. In International Congress of Neuropathology, 5th, Zurich, edited by F. Luthy and A. Bischoff, Amsterdam. Excerpta Medica Foundation, pp. 979-980.

MCFARLAND, R. A., WARREN, B. and KAVIS. C. (1958). Alterations in critical nicker frequency as a function of age and light: dark ratio. Journal of Experimental Psychology 56, 529-538.

MCGEER, P. L., MCGEER, E. G. and SUZUKI, J. S. (1977). Aging and extrapyramidal function. Archives of Neurology 34, 33-35.

MEIER-RUGE, W. (1975). Experimental pathology and pharmacology in brain research and aging. Life Sciences 17, 16271636.

MERGLER, N. L., DUSIK, J. B. and HOYER, W. J. (1977). Central/incidental recall and selective attention in young and elderly adults. Experimental Aging Research 3, 4960.

MILLER, C. A. and LEVINE, E. M. (1974). Effects of aluminum salts on cultured neuroblastoma cells. Journal of Neurochemistry 22, $751-758$.

MILNER, B. (1970). Memory and the medial temporal regions of the brain. In Biology of Memory, edited by K. H. Pribram and D. E. Broadbent, New York, Academic Press, pp. 29-50.

MISIAK, H. (1951). The decrease of critical flicker frequency with age. Science II3, 551552.

MUNDY-CASTLE, A. C. (1953). An analysis of central responses to photic stimulation in normal adults. Electroencephalography \& Clinical Neurophysiology 5, 1-22.

OBRIST, W. D., CHIVIAN, E., CRONQVIST, S. and INGVAR, D. H. (1970). Regional cerebral blood flow in senile and presenile dementia. Neurology 20, 315-322.

OHARA, P. T. (1972). Electron microscropial study of the brain in Down's syndrome. Brain 95, 68I-684.

OOKA, H., SEGALL, P. E. and TIMIRAS, P. S. (1978). Neural and endocrine development after chronic tryptophan deficiency in rats. II. Pituitary-thyroid axis. Mechanisms of Ageing and Development 7 . 19-24.

ORGEL, L. E. (1963). The maintenance of the accuracy of protein synthesis and its relevance to aging. Proceedings of the National Academy Sciences 49, 517-521.

PATCH, M. S. (1977). Age-dependent changes in the oxidative metabolism in rat brain. Journal of Gerontology 32. 643-646. 
PERRY, E. K., PERRY, R. H., GIBSON, P. H., BLESSED, G. and TOMLINSON, B. E. (1977). A cholinergic connection between normal aging and senile dementia in the human hippocampus. Neuroscience Letters 6, 85-89.

PHILliPS, A. G. and FIBIGER, H. C. (1973). Dopaminergic and noradrenergic substrates of postive reinforcement: Different effects of D- and L-amphetaminc. Science 179, 575 577.

PLEMONS, J. K., WILLIS, S. L. and BALTES, P. B. (1978). Modifiability of fluid intclligence in aging: A short-term longtitudinal training approach. Journal of Gerontology 33, 224-23I.

PLOSKI, H. A., LEVITA, E. and RIKLAN, M. (1966). Impairment of voluntary movement in parkinson's disease in relation to activation level autonomic malfunction and personal rigidity. Psychosomatic Medicine 28, 70-77.

RABBITT, P. (1965). An age-decrement in the ability to ignore irrelevant information. Journal of Gerontology 20, 233-238.

READING, V. (1968). Disability glare and age. Vision Research 8, 207-214.

RETZLAFF, E. and FONTAINE, J. (1965). Functional and structural changes in motor neurons with age. In Behavior, Aging and the Nervous Systems, Springfield, Illinois, C. C. Thomas, pp. 340-352.

RIKLAN, M., LEVITA, E. and MISIAK, $H$. (1970). Critical flicker frequency and integrative functions in parkinsonism. Journal of Psychology 75, 45-51.

ROBERTS, J., GOLDBERG, P. B. and BASKIN, S. I. (1976). Biochemical changes in the central nervous system with age in the rat. Experimental Aging Research 2, 61-74.

ROBINSON, D. S., SOURKES, T. L., NIES, A.. HARRIS, L. S., SPECTOR, S., BARTLETT, D. L. and KAYE, I. S. (1977). Monoamine metabolism in human brain. Archives of General Psychology 34, 89-92.

ROSS, M. H. and LUSTBADER, E. (1976). Dietary practices and growth responses as predictors of longevity. Nature 262, 548-553.

SACCUZZO, D. P., HIRT, M. and SPENCER, T. (1974). Back ward masking as a measure of attention in schizophrenics. Journal of Abnormal Psychology 83, 512-522.

SALTHOUSE, T. A. (1978). The role of memory in the age decline in digit-symbol substitution performance. Journal of Gerontology 33, 232-238.

SAMORAJSKI, T. and ROLSTEN, C. (1976). Chlorpromazine and aging in the brain. Experimental Gerontology 11, 141-147.

SCHAIE, K. W., LAVOUVIE, G. V. and BUECH, B. V. (1973). Generational and cohort-specific differences in adult cognitive functioning. Developmental Psychology 9, 151-166.

SCHEJBEL, M. E., LINDSAY, R. D., TOMIYASU, $U$. and SCHEIBEL, A. B. (1975). Progressive dendritic changes in aging human cortex. Experimental Neurology $47,392-403$.
SCHEIBEL, M. E., TOMIYASU, U. and SCHEIBEL, A. B. (1976). Dendritic changes in the aging human rhinencephalon. Transactions of the American Neurological Association 101, 23-26.

SCHNEIDER, N. G., GRITZ, E. R. and JARVIK, M. E. (1975). Age differences in learning, immediate and one week delayed recall. Gerontologia 21, 10-20.

SEGALL. P. E., OOKA, H., ROSE. K. and TIMIRAS, P. S. (1978). Neural and endocrine development after chronic trypotphan deficiency in rats: 1. Brain monomine and ptituitary responses. Mechanisms of Ageing and Development 7, 1-17.

SHADER, R. I., HARMATZ, J. S. and SALTZMAN, C. (1974). A new scale for clinical assessment in geriatric patients: Sandoz clinical assessment in geriatrics (SCAG). Journal of the American Geriatric Society 22, 107-113.

SIMARD, D. (1971). Regional blood and its regulation in dementia. Brain 94, 273-288.

SOTGIU G., CUSSINI, G., CHIERICI, F. and VANCINI, B. (1960). Senile adrenal hyper-medullism. Panminerva Medicine 2 , $1-5$.

SPANO, P. F., KUMAKURA, K., TONON, G. C., GOVONI, S. and TRABUCCHI, M. (1975). LSD and dopamine sensitive adenylate cylase in various rat brain areas. Brain research 93, 164-167.

SPANO, P. F. and TRABUCCHI, M. (1978). Interaction of ergot alkaloids with dopaminergic receptors in the rat itriatum and nucleus accumbens. Gerontology 24 , Suppl. I. 106-114.

SPILLANE, J. A., WHITE P., GOODHARDT, M. J., FLACK, R. H. A., BOWEN, D. M. and DAVISON, A. N. (1977). Selective vulnerability of neurons in organic dementia. Nature 266, 558-559.

SPIRDUSCO, W. W. (1975). Reaction and movement time as a function of age and physical activity level. Journal of Gerontology 30, 435-440.

SPIRDUSO, W. W. and CLIFFORD, P. (1978). Replication of age physical activity effects on reaction and movement time. Journal of Gerontology 33, 26-30.

STEIN, D. G. and FIRL, A. C. (1976). Brain damage and reorganization of function in old age. Experimental Neurology 52, 157167.

SUN, A. Y. (1976). Aging and in vivo norepinephrine-uptake in mammalian brain. Experimental Aging Research 2, 207-220.

SUN, A. Y. and SAMORAJSK1, T. (1975). The effects of age and alcohol on Na-K ATPase activity of the whole homogenate and synaptosomes prepared from mouse and human brain. Journal of Neurochemistry 24 , 161-164.

SUN, A. Y. and SEAMAN, R. N. (1977). The effect of aging on synaptosomal $\left(\mathrm{Ca}^{2+}\right)$ transport in the brain. Experimental Aging Research 3, 107-116.

TERRY, R. D. and PENA, C. (1965). Experimental production of neurofibrillary degeneration. 2. Electron microscopy, phosphatase histochemistry and electron probe analysis. Journal of Neuropathology and Experimental Neurology 24, 200-210.

TONNA, E. A. and SiNGH, I. J. (1976). An autoradiographic investigation of ${ }^{3} \mathrm{H}$ Uridine utilization by aging mouse cartilage cells. Experimental Gerontology 11, 231241.

UNGERSTEDT. W. (197I). Mechanism of action of L-DOPA studied in an experimental Parkinson model. In Monoamines, Noyaux Gris Centraux et Syndrome de Parkinson, edited by J. de Ajuriaguerra and G. Gauthier, Paris, Masson and Georg. pp. 165-170.

VICTOR, M., ADAMS, R. D. and COLLINS, G. H. (1971). The Wernicke-Korsakoff Syndrome, Philadelphia, R. A. David, pp. $71-135$.

VIJAYAN, V. K. (1977). Cholinergic enzymes in the cerebellum and the hippocampus of the senescent mouse. Experimental Gerontology, 12, 7-11.

VRIES, H. A., DE (1971). Exercise intensity threshold for improvement of cardiovascularrespirat ory function in older men. Geriatrics 26, 94-101.

WEISS, A. D. (1959). Sensory functions. In Handbook of Aging and the Individual, edited by I. E. Birren, Chicago, University of Chicago Press, pp. 503-542.

WHANGER, A. D. and WANG, H. S. (1974). Clinical correlates of vibratory sense in the elderly psychiatric patients. Journal of Gerontology 29, 39-45.

WhITE, P., GOODHARDT, M. J., KEET, J. P., HILEY, C. R.. CARRASCO, L. H., WILLIAMS, I. E. I. and BOWEN, D. M. (1977). Neocortical cholinergic neurons in elderly people. Lancet, 1,668-671.

WILLIAMS, M. (1970). The psychological assessment of geriatric patients. In the Psychological Assessment of Mental and Physical Handicaps edited by P. J. Mittler, London, Methuen, pp. 319-339.

WINN, F. J. and ELIAS, J. W. (1977). Age, rate and instructional conditions; empirical support against the pacing variable. Experimental Aging Research 3, 305-324.

WISNIEWSKI, H. M. and TERRY, R. D. (1976). Neuropathology of the aging brain. In Neurobiology of Aging, cdited by R. D. Terry and S. Gershon, New York, Raven Press, pp. 265-280.

WOLF, E. (1960). Glare and age. Archives of Ophthalmology 64, 502-514.

YATES, A. J. (1966). Data processing levels and thought disorder in schizophrenics. Australian Journal of Psychology 18, 103107.

YATES, A. J. (1966). Data processing levels and thought disorder in schizophrenics. Australian Journal of Psychology 18, 103107.

YATES, A. J. and KORBOOT, P. (1970). Speed of perceptual functioning in chronic nonparanoid schizophrenics. Journal of Abnormal Psychology 76, 453-461.

ZELINSKI, E. M., WALSH, D. A. and THOMPSON, L. W. (1978). Orienting task effects on EDR and free recall in three age groups. Journal of Gerontology 33, 239-245. 